\section{Morphology and Postharvest Performance of Geogenanthus undatus C. Koch \& Linden 'Inca' after Application of Ancymidol or Flurprimidol}

\author{
Amy L. Burton \\ Department of Horticulture, The Pennsylvania State University, 103 Tyson \\ Building, University Park, PA 16802-4200
}

\author{
Svoboda V. Pennisi ${ }^{1}$ \\ Department of Horticulture, University of Georgia, UGA Griffin Campus, \\ 1109 Experiment Street, Griffin, GA 30223
}

Marc W. van Iersel

Department of Horticulture, The University of Georgia, 1111 Plant Sciences Building, The University of Georgia, Athens, GA 30602-7273 Additional index words. foliage plants, irradiance, photosynthetic photon flux, plant growth
regulator

\begin{abstract}
Excessive internode elongation and leaf senescence are common problems with foliage plants transferred to interiorscapes. The authors' objective was to determine whether plant growth regulators applied late in the production cycle could control growth during production and improve interiorscape performance. In addition, the authors wanted to quantify the effect of irradiance on growth and morphology during the production phase and in the interiorscape. Geogenanthus undatus $\mathbf{C}$. Koch \& Linden 'Inca' plants were grown under one of two photosynthetic photon fluxes $(P P F ; 50$ or $\left.130 \mu \mathrm{mol} \cdot \mathrm{m}^{-2} \cdot \mathrm{s}^{-1}\right)$, and were treated with either $\alpha-($ methylethyl)- $\alpha-[4-($ trifluoromethoxy)phenyl]-5-pyrimidinemethanol (flurprimidol) or $\alpha$-cyclopropyl- $\alpha$-(4-methoxyphenyl)-5pyrimidinemethanol (ancymidol) during the week 12 production, at $0.5,1.0$, or $1.5 \mathrm{mg} / \mathrm{pot}$ of active ingredient. The high $P P F$ resulted in significantly higher leaf, stem, root, and total dry weight, and leaf area, but lower leaf area ratio (leaf area divided by total plant dry weight) compared with the low $P P F$. After production, plants were placed in a simulated interior environment for 4 months under a $P P F$ of $15 \mu \mathrm{mol} \cdot \mathrm{m}^{-2} \cdot \mathrm{s}^{-1}$ and a photoperiod of 12 hours/day. Production PPF did not affect most growth parameters after 4 months in the interior environment, except for the root-to-shoot ratio. Under lowproduction $P P F$, root-to-shoot ratios were lower than under high-production $P P F$. For both growth regulators, the height and growth indexes were lower than for control plants, but flurprimidol offered greater control than ancymidol. Flurprimidol-treated plants had lower root dry weight and root-to-shoot ratios compared with ancymidol-treated and control plants. Applications of ancymidol or flurprimidol administered to G. undatus $\mathbf{C}$. Koch \& Linden 'Inca' late during the production cycle resulted in significant growth control and, therefore, superior plant performance throughout the postharvest period.
\end{abstract}

Geogenanthus undatus is a newly introduced cultivar of the species G. undatus C. Koch \& Linden (seersucker plant), native to Peru (Graf, 1963). The species has a low-

Received for publication 24 Aug. 2006. Accepted for publication 11 Nov. 2006.

Research materials donated by Agri-Starts, Apopka, Fla.; Fafard, Anderson, S.C.; and SePRO Corporation, Carmel, Ind.

This paper is a portion of a thesis submitted by A.B. in partial fulfillment of a Master of Science degree. We thank Orville Lindstrom and Carol Robacker for review of the manuscript and constructive criticism, and Matthew Atkinson and Dan Hall for their help with the statistical analyses.

${ }^{1}$ To whom reprint requests should be addressed; e-mailbpennisi@uga.edu. synthetic photon flux $(P P F)$ in postharvest settings are suboptimal for plant growth, even for many shade-adapted species. Low $P P F$ can cause foliar chlorosis or necrosis, premature leaf senescence, or internode stretching (Conover and Poole, 1981). These undesirable responses lead to frequent plant replacement, high costs, and consumer dissatisfaction. Growers often acclimate foliage plants to lower $P P F$ during production to improve postharvest performance.

Production PPFs have been shown to affect growth parameters of foliage plants. Species-specific responses have been documented for various growth parameters, such as growth index, dry weight, and root-toshoot ratio (Conover and Poole, 1981). In addition, production irradiance also affects acclimation. Because the majority of foliage plants are sold for the interiorscape market, postharvest performance is an important aspect of the overall evaluation of a particular species or cultivar for the foliage industry.

Plant growth regulator (PGR) type and concentration have been shown to affect postharvest performance of foliage plants (Cox and Whittington, 1988; Davis, 1987). Timing of application is considered critical to the efficacy of PGRs; they are generally applied early during the production cycle. However, by the time the plant is installed in the postharvest environment, the growth control exerted by the PGR may be less, and thus the PGR effect may not carry over to the interiorscape. If the PGR is applied later during the production cycle, and at an appropriate concentration, the growth control and related enhanced plant quality may be extended into the postharvest period. In the current study, drench applications of $\alpha$-cyclopropyl- $\alpha$-(4methoxyphenyl)-5-pyrimidinemethanol (ancymidol) or $\alpha$-(methylethyl)- $\alpha$-[4-(trifluoromethoxy)phenyl]-5-pyrimidinemethanol (flurprimidol) were administered to Geogenanthus during the later part of the production cycle. The purpose of a late-production application was to ensure growth control throughout the postharvest period. In addition, we hoped that late application of PGRs would slow down growth during the latter part of production, allowing the plants to accumulate starch instead of allocating carbohydrates to new growth. Starch reserves could be used by the plants after transfer to a low irradiance environment and potentially improve their performance in interiorscapes.

The objectives of this study were to evaluate the effects of $P P F$ and PGR on growth of G. undatus C. Koch \& Linden 'Inca' during production, to determine whether the responses to the PGRs are similar at different irradiance levels, and, lastly, to evaluate the postharvest performance of G. undatus C. Koch \& Linden 'Inca' in response to $P P F$ and PGR applied late during the production cycle.

\section{Materials and Methods}

marketable material, growers need production guidelines for irradiance, temperature, and nutrition regimes, as well as growth control.

The majority of tropical foliage plants are produced for use indoors. Generally, photo-

\section{Production phase}

Plant material. Tissue culture liners of G. undatus C. Koch \& Linden 'Inca' 
(Agri-Starts, Apopka, Fla.) were planted in square pots (volume, $793 \mathrm{~cm}^{3}$ ), using a peatlite medium (Fafard 2P, 65\% Canadian sphagnum peat-35\% horticultural perlite; Fafard, Anderson, S.C.). Plants were grown in a double-polyethylene Quonset-style greenhouse, covered with a double layer of $50 \%$ shade cloth. The temperature control in the greenhouse was set at $21{ }^{\circ} \mathrm{C}$ day $/ 18{ }^{\circ} \mathrm{C}$ night (Wadsworth Systems; Arvada, Colo.). Plants were grown on 12 ebb-and-flow benches $\left(1.2 \times 2.4 \mathrm{~m}^{2}\right.$; Midwest GroMaster, St. Charles, Ill.). Fertilizer solutions were stored in plastic barrels $(210 \mathrm{~L})$ and pumped into the watertight trays of the ebb-and-flow system using submersible pumps (NK-2; Little Giant, Oklahoma City, Okla.). Media fertility levels were monitored weekly on a random sample of 12 to 24 plants using the pour-through method (Yeager, et al., 1997). Distilled water $(50 \mathrm{~mL})$ was poured into each pot and allowed to drain; leachate was collected, and $\mathrm{pH}$ and electrical conductivity (EC) were analyzed (Myron L Agrimeter AG-6; Metex Corporation Ltd., Toronto, Canada). Medium fertility levels were found to be within appropriate levels on all testing dates (EC, 1.3-1.6 dS.m ${ }^{-1}$; $\mathrm{pH}, 5.5-6.5$ ). Tissue and media samples were sent to MicroMacro Laboratories (Athens, Ga.) for analysis at the midpoint of production. Macro- and micronutrient levels in tissue were found to be within appropriate ranges, based on general recommendations for foliage plants (Reed, 1996).

Treatments. Two production irradiance levels were achieved by using a single layer of $50 \%$ black shade cloth placed over half the benches (designated low PPF treatment), whereas the remaining six benches received ambient irradiance levels and were designated as the high $P P F$ treatment. The actual shade structure provided some additional shading. Measurement of the high and low irradiance levels were taken as instantaneous measurements (2 PM on 5 May 2004), and were found to be $130 \mu \mathrm{mol} \cdot \mathrm{m}^{-2} \cdot \mathrm{s}^{-1}$ or 50 $\mu \mathrm{mol} \cdot \mathrm{m}^{-2} \cdot \mathrm{s}^{-1}$ respectively.

Drench applications of ancymidol [0.5, $1.0,1.5 \mathrm{mg} /$ pot of active ingredient (a.i.)] or flurprimidol $(0.5,1.0,1.5 \mathrm{mg} /$ pot a.i.; SePRO Corporation, Carmel, Ind.) were applied $(59 \mathrm{~mL} /$ pot). Control plants received a drench of deionized water $(59 \mathrm{~mL} / \mathrm{pot})$. Plant growth regulator treatment was administered during week 12 of production. Plant growth regulator dosages were determined based on previous work (Pennisi et al., 2003) and label recommendations.

Measurements. Morphological data were taken on all plants (height and two perpendicular widths, leaf tip to leaf tip) at the end of production. Height was measured from shoot base to the apex. These data were used to calculate growth index [size $=($ height + width $_{1}+$ width $\left.\left._{2}\right) / 3\right]$.

After 16 weeks of production, plants were prepared for destructive sampling by removing growing media from roots, and by physical separation of roots, stems, and leaves. Whole-plant leaf areas were taken with a leaf area meter (model 3100 Leaf Area Meter; LI-COR, Lincoln, Nebr.). For each plant, the roots, stems, and leaves were placed in separate bags and dried in a forced-air oven maintained at $80{ }^{\circ} \mathrm{C}$ for a week. Leaf area ratio (LAR) was calculated as leaf area divided by total plant dry weight.

Quantitative enzymatic starch analysis was performed separately for dry root, stem, and leaf tissue, according to the method of lo Bianco and Rieger (2002). The starch analysis was only performed on control and flurprimidol-treated plants.

At the end of production, physiological experiments were performed on 12 representative plants to determine photosynthesis at nine PPFs. Each plant was exposed to progressively higher $P P F s(\approx 0,10,20,30,40$, $50,100,400$, and $\left.700 \mu \mathrm{mol} \cdot \mathrm{m}^{-2} \cdot \mathrm{s}^{-1}\right)$. Carbon dioxide exchange concentrations were taken on the most recently matured leaf, midway between the mid rib and leaf edge, and midway between the petiole and leaf tip (CIRAS-1; PP-Systems, Amesbury, Mass.). Dark respiration $\left(\mathrm{R}_{\mathrm{d}}\right)$, maximum light use efficiency (LUE), and light-saturated gross photosynthesis $\left(\mathrm{P}_{\text {gmax }}\right)$ were estimated from a nonlinear regression (SigmaPlot v.10 software package; Systat Software, Richmond, Calif.):

$$
\mathrm{P}_{\mathrm{n}}=\left(\mathrm{P}_{\text {gmax }}\right)\left[1-\mathrm{e}^{(-\mathrm{LUE})(\mathrm{PPF}) / \text { Pgmax }}\right]+\mathrm{R}_{\mathrm{d}}
$$

where $\mathrm{P}_{\mathrm{n}}$ is net photosynthetic concentration and, $\mathrm{P}_{\mathrm{gmax}}$ is light-saturated gross photosynthetic concentration, LUE is maximum light use efficiency, and $R_{d}$ is dark respiration (here expressed as a negative value, because it represents a $\mathrm{CO}_{2}$ efflux from the plant). The light compensation point was determined by solving Eq. 1 for $P P F$ and a $\mathrm{P}_{\mathrm{n}}$ of $0 \mu \mathrm{mol} \cdot \mathrm{m}^{-2} \cdot \mathrm{s}^{-1}$. The light saturation point was determined as the $P P F$ at which $\mathrm{P}_{\mathrm{n}}$ was $95 \%$ of light-saturated net photosynthesis $\left[\mathrm{P}_{\mathrm{n}}=0.95 \times\left(\mathrm{P}_{\text {gmax }}+\mathrm{R}_{\mathrm{d}}\right)\right]$. The units for all parameters are micromoles per square meter per second, with the exception of the unitless LUE, which is a measure of the maximum moles of $\mathrm{CO}_{2}$ fixed per mole of incoming light (the slope of the light response curve at a $P P F$ of $0 \mu \mathrm{mol} \cdot \mathrm{m}^{-2} \cdot \mathrm{s}^{-1}$ ).

Experimental design. Three subrepetitions were randomized within each bench (total of 21 plants/table). A subrepetition consisted of seven plants: one plant from each of the three dosages of ancymidol, one plant from each of three dosages of flurprimidol, and one control plant. On each table, the three subrepetitions were designated as part of studies I (morphology and carbohydrate analyses), II (photosynthesis analysis), and III (postharvest analysis). The experimental design was a completely randomized split plot with 12 whole plots (benches), and the variables of PGR type and dosage nested within $P P F$

Data were analyzed using the general linear model in Statistical Analysis Software v.9 (SAS Institute, Cary, N.C.) to test for twoway and three-way interactions and significant correlations $(P<0.05$ was considered statistically significant). PROC General Linear Model was used for the enzymatic starch analysis. Means separation analysis (Fisher's protected LSD) was used to analyze the data further. Significance of the main effects (PPF, PGR application) and their interaction were determined using analysis of variance, whereas more specific comparisons were made with contrast statements. Contrast statements were generated based on the fact that PPF, PGR type, and PGR concentration were treated as classification variables.

\section{Postharvest phase}

After 16 weeks of production, one or two plants from each experimental unit (one set of subrepetitions from eight benches, and two sets of subrepetitions from four benches) were placed in four growth chambers under simulated interior conditions [temperature, $21{ }^{\circ} \mathrm{C}$ day $/ 18^{\circ} \mathrm{C}$ night; $P P F, 0.65 \mathrm{~mol} \cdot \mathrm{m}^{-2} \cdot \mathrm{d}^{-1}$ $\left(15 \mu \mathrm{mol} \cdot \mathrm{m}^{-2} \cdot \mathrm{s}^{-1}\right)$; photoperiod, $12 \mathrm{~h} / \mathrm{d}$ ]. Plants were irrigated weekly and fertigated biweekly with a $100 \mathrm{mg} \cdot \mathrm{L}^{-1} \mathrm{~N}$ fertilizer solution [Peter's 24-8-16 Tropical Foliage (24N-3.4P-13.4K); Scotts, Marysville, Ohio). The water and nutrient solutions were delivered through subirrigation.

After 18 weeks in growth chambers, morphological measurements were taken (height and two perpendicular widths, leaf tip to leaf tip). These data were used to calculate growth index. The number of senesced leaves per plant was recorded. Growing medium was washed from the roots. For each plant, the roots and shoots were separated and dried in a forced-air oven maintained at $80{ }^{\circ} \mathrm{C}$ for a week.

Experimental design. The experimental design for the postharvest study was a randomized split plot with 16 whole plots consisting of seven plants each (one from each PGR treatment). Furthermore, whole plots were arranged in a randomized complete block design, with each growth chamber representing a block holding four plots each (two from high $P P F$ and two from low $P P F$ ). Statistical analysis was performed using the SAS software package v.9 and PROC MIXED procedure (SAS Institute, Cary, N.C.). Significance of the main effects $(P P F$, PGR application) and their interaction were determined using analysis of variance, whereas more specific comparisons were made with contrast statements. Contrast statements were generated based on the fact that $P P F$, PGR type, and PGR dosage were treated as classification variables, with $P<0.05$ considered statistically significant. When main or interactive effects were significant, mean separation was accomplished through a series of $t$ test comparisons among PGR treatments.

\section{Results and Discussion}

Production phase. All PGR treatments affected height of $G$. undatus C. Koch \& Linden 'Inca' compared with controls (Tables 1 and 2), whereas $P P F$ did not. Increasing the dosage of either ancymidol or flurprimidol had little effect on plant 
Table 1. Separation of means based on irradiance and plant growth regulator treatments for growth parameters in Geogenanthus undatus C. Koch \& Linden 'Inca'.

\begin{tabular}{llllllll}
\hline & $\mathrm{H}(\mathrm{cm})$ & GI $(\mathrm{cm})$ & TDW $(\mathrm{g})$ & RDW $(\mathrm{g})$ & LA $\left(\mathrm{cm}^{2}\right)$ & LAR & R:S \\
\hline$P P F\left(\mu \mathrm{mol} \cdot \mathrm{m}^{-2} \cdot \mathrm{s}^{-1}\right)$ & & & & & & & \\
130 & $11.3 \mathrm{a}^{\mathrm{z}}$ & $21.7 \mathrm{a}$ & $8.1 \mathrm{a}$ & $3.8 \mathrm{a}$ & $735 \mathrm{a}$ & $201 \mathrm{a}$ & $0.92 \mathrm{a}$ \\
50 & $11.2 \mathrm{a}$ & $20.5 \mathrm{a}$ & $5.6 \mathrm{~b}$ & $2.5 \mathrm{~b}$ & $581 \mathrm{a}$ & $232 \mathrm{~b}$ & $0.85 \mathrm{a}$ \\
PGR $(\mathrm{mg} /$ pot a.i.) & & & & & & & \\
0 & $14.4 \mathrm{a}$ & $24.2 \mathrm{a}$ & $7.9 \mathrm{a}$ & 3.4 & $784 \mathrm{a}$ & $223 \mathrm{a}$ & $0.80 \mathrm{c}$ \\
Ancymidol 0.5 & $11.6 \mathrm{~b}$ & $21.3 \mathrm{~b}$ & $7.1 \mathrm{abc}$ & 3.2 & $709 \mathrm{ab}$ & $224 \mathrm{a}$ & $0.80 \mathrm{c}$ \\
Ancymidol 1.0 & $11.1 \mathrm{bc}$ & $20.8 \mathrm{bc}$ & $6.6 \mathrm{bc}$ & 3.0 & $647 \mathrm{~b}$ & $218 \mathrm{ab}$ & $0.87 \mathrm{bc}$ \\
Ancymidol 1.5 & $10.2 \mathrm{c}$ & $20.8 \mathrm{bc}$ & $6.0 \mathrm{c}$ & 2.5 & $615 \mathrm{bc}$ & $217 \mathrm{ab}$ & $0.74 \mathrm{c}$ \\
Flurprimidol 0.5 & $10.9 \mathrm{bc}$ & $20.9 \mathrm{bc}$ & $7.3 \mathrm{ab}$ & 3.4 & $681 \mathrm{ab}$ & $213 \mathrm{bc}$ & $0.98 \mathrm{ab}$ \\
Flurprimidol 1.0 & $10.5 \mathrm{bc}$ & $20.0 \mathrm{c}$ & $6.6 \mathrm{bc}$ & 3.3 & $649 \mathrm{~b}$ & $217 \mathrm{ab}$ & $0.97 \mathrm{ab}$ \\
Flurprimidol 1.5 & $10.2 \mathrm{c}$ & $19.7 \mathrm{c}$ & $6.3 \mathrm{bc}$ & 3.2 & $523 \mathrm{c}$ & $208 \mathrm{c}$ & $1.05 \mathrm{a}$ \\
\hline
\end{tabular}

${ }^{\mathrm{z}}$ Any two means within a column not followed by the same letter are significantly different at $P<0.05$ using a Fisher's protected LSD mean separation. Plant growth regulator (PGR) effects on root dry weight (RDW) were not analyzed, because of the absence of a significant PGR effect (Table 2).

An interaction did not exist between irradiance and PGR dosage for the growth parameters shown.

$P P F$, photosynthetic photon flux; H, height; GI, growth index; TDW, total dry weight; LA, leaf area; LAR, leaf area ratio; $\mathrm{R}: \mathrm{S}$, root-to-shoot ratio.

Table 2. Analysis of variance of main effects and contrast statements for the effects of photosynthetic photon flux $(P P F)$ and plant growth regulator (PGR) on morphological response in Geogenanthus undatus C. Koch \& Linden 'Inca'.

\begin{tabular}{lccccccccc}
\hline & \multicolumn{10}{c}{ Growth parameters } \\
\cline { 2 - 11 } Effect $^{\mathrm{z}}$ & $\mathrm{H}$ & $\mathrm{GI}$ & TDW & RDW & SDW & LDW & LA & LAR & $\mathrm{R}: \mathrm{S}$ \\
\hline$P P F$ & $\mathrm{NS}$ & $\mathrm{NS}$ & 0.01 & 0.02 & $-\mathrm{y}$ & - & 0.07 & $<0.0001$ & $\mathrm{NS}$ \\
PGR treatment & $<0.0001$ & $<0.0001$ & 0.03 & $\mathrm{NS}$ & - & - & 0.005 & 0.006 & 0.002 \\
$P P F \times$ PGR treatment & $\mathrm{NS}$ & $\mathrm{NS}$ & $\mathrm{NS}$ & $\mathrm{NS}$ & 0.04 & 0.05 & NS & NS & NS \\
PGR all vs. control & $<0.0001$ & $<0.0001$ & 0.005 & - & $<0.0001$ & 0.0006 & 0.003 & 0.04 & $\mathrm{NS}$ \\
PGR A vs. control & $<0.0001$ & $<0.0001$ & 0.006 & - & 0.0007 & 0.007 & 0.02 & NS & NS \\
PGR F vs. control & $<0.0001$ & $<0.0001$ & 0.01 & - & $<0.0001$ & 0.0002 & 0.001 & 0.005 & 0.004 \\
PGR A vs. PGR F & NS & NS & NS & - & NS & NS & NS & 0.01 & $<0.0001$ \\
Dosage effect & NS & 0.04 & 0.04 & - & NS & NS & 0.02 & NS & NS \\
Dosage effect, & & & & & & & & & \\
linear & NS & NS & 0.01 & - & NS & NS & 0.005 & NS & NS \\
\hline
\end{tabular}

${ }^{\mathrm{z}}$ Use of contrast statement analysis was based on significance of corresponding main effect, at a level of $P<0.05$.

y -, values not considered based on significance of a main or interactive effect of photosynthetic photon flux $(P P F)$ and plant growth regulator (PGR) treatments.

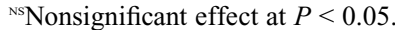

$\mathrm{H}$, height; GI, growth index; TDW, total dry weight; RDW, root dry weight; SDW, stem dry weight; LDW, leaf dry weight; LA, leaf area; LAR, leaf area ratio; R:S, root-to-shoot ratio; PGR A, ancymidol; PGR F, flurprimidol.

height (Table 2). Drench applications of ancymidol also decreased height in four cultivars of sunflower (Starman et al., 1989). Whipker et al. (2004) found that flurprimidol caused a strong linear decrease in sunflower height up to a concentration of $2 \mathrm{mg}$ a.i./15-cm pot. However, increasing concentration beyond $2 \mathrm{mg}$ a.i./pot did not offer any further control of height. All PGR applications resulted in smaller plants, and this decrease was dosage dependent (Tables 1 and 2). As was the case for plant height, there was no difference between the two PGRs.

Studies of the interaction of PGRs and $P P F$ have not been as common as experiments focused solely on the growth-controlling characteristics of PGRs (i.e., height, internode length). Thus, information on the combined effect of irradiance and PGR on dry weight is somewhat limited, especially when considering four separate dry weight quantities (leaf, stem, root, total). Photosynthetic photon flux alone has been shown to change dry weight accumulation and partitioning in shade-obligate plants. Dracaena (Dracaena sanderana hort Sander ex. Mast.) exhibited quadratic responses in dry weight of root, stem, and shoot when grown under four different shading levels $(47 \%, 63 \%$, $80 \%$, or $91 \%$ ) (Vladimirova et al., 1997). Moderate shading $(63 \%$ or $80 \%)$ allowed for the greatest accumulation of dry matter in all fractions, whereas the highest and lowest irradiance levels resulted in relative reductions in dry matter accumulation. Depending on irradiance requirements of the species in question, extremely high and low $P P F S$ are likely to cause reductions in growth, resulting from inhibition of photosynthesis at either extreme.

Total dry weight was affected by both $P P F$ and PGR concentration, but no significance was found for the interaction of these two variables (Tables 1 and 2). Low $P P F$ reduced total biomass by $30 \%$ compared with high $P P F$, with a similar effect on root dry weight. Geogenanthus has not been widely grown, and therefore optimum production parameters are yet to be determined. Our data indicate that low $P P F$ may delay accumulation of adequate dry matter for marketable Geogenanthus plants within a reasonable production period. Both PGRs negatively affected total dry weight of $G$. undatus C. Koch \& Linden 'Inca' and this reduction was correlated with the PGR dosage (Tables 1 and 2). Plant growth regulators did not have an effect on root dry weight. High $P P F$ resulted in greater root dry weight than low $P P F$, regardless of PGR treatment (Tables 1 and 2). The interaction of $P P F$ with PGR treatment was significant for leaf dry weight (Table 2), and the effects were similar as for stem dry weight. Under high $P P F$, control plants had higher leaf dry weight than plants treated with either PGR, and there was no effect of PGR concentration on leaf dry weight (Tables 2 and 3). Plant growth regulator applications did not affect leaf dry weight under low-irradiance conditions. Control plants grown in high $P P F$ had $87 \%$ greater leaf dry weight than controls grown under low $P P F$.

Leaf area in Geogenanthus was unaffected by irradiance, but tended to be higher at high $P P F(P=0.71)$. This is in contrast to the general notion that leaf areas tend to increase under low irradiance during the process of light acclimation (Taiz and Zeiger, 2002). The application of either ancymidol or flurprimidol caused a decrease in leaf area, and this effect was similar for both PGRs (Tables 1 and 2). As with other morphological changes, leaf area tends to decrease as PGR dosage is increased (Thetford et al., 1995). Because of the tendency to increase leaf area, plants grown under a lower $P P F$ tend to have a higher LAR than plants grown under high $P P F$ (Makino et al., 1997). Both $P P F$ and PGR dosage affected LAR, although an interaction between these two factors was not observed (Tables 1 and 2). As expected, plants grown under low $P P F$ had a consistently higher LAR than high $P P F$ plants of comparable PGR dosages. Flurprimidol reduced LAR compared with the control plants, whereas ancymidol did not (Tables 1 and 2).

The root-to-shoot ratio was increased by flurprimidol but not ancymidol (Tables 1 and 2 ). This is related to the decrease in leaf and stem dry weight of flurprimidol-treated plants, because root dry weight was unaffected by flurprimidol. Photosynthetic photon flux did not affect the root-to-shoot ratio.

Plant growth regulators have been shown to change carbon partitioning patterns and increase starch production in several species (Mehouachi et al., 1996; Pennisi et al., 2003). In general, the major starch storage organ varies by species (Davis et al., 1988). For this reason, we performed starch analysis separately on stems, leaves, and roots. Increased carbohydrate pools would allow for the continuation of maintenance respiration, which would be of particular importance for plants experiencing low $P P F$ stress, as in a postharvest environment. However, the starch concentrations in leaves, stems, and roots were unaffected by production $P P F$ or PGR treatments (data not shown).

Results from the photosynthesis-light response measurements did not indicate 
differences among controls and treated plants, regardless of $P P F$ or PGR treatment. A light response curve from a representative plant revealed that net photosynthesis in $G$. undatus C. Koch \& Linden 'Inca' is low (Fig. 1). The light compensation point was 2.8 $\mu \mathrm{mol} \cdot \mathrm{m}^{-2} \cdot \mathrm{s}^{-1}$, the light saturation point was $64 \mu \mathrm{mol} \cdot \mathrm{m}^{-2} \cdot \mathrm{s}^{-1}$, and the LUE was 0.159 $\mathrm{mol} \cdot \mathrm{mol}^{-1}$. These data are consistent with the slow growth observed during both production and postharvest phases. Shade-obligate plants have lower light compensation and saturation points than sun-obligate plants. In a study on four understory herbaceous plants [Arisaema triphyllum L. (Schott), Erythronium americanum Ker, Podophyllum peltatum L., and Smilacina racemosa L. (Desf.)], three of the four species were considered shade-obligate, whereas E. americanum was considered a sun plant (Hull, 2002). Light compensation points were lower for the shade-obligate species [Podophyllum $\left(11 \mu \mathrm{mol} \cdot \mathrm{m}^{-2} \cdot \mathrm{s}^{-1}\right)$, Arisaema ( $5 \mu \mathrm{mol} \cdot \mathrm{m}^{-2} \cdot \mathrm{s}^{-1}$ ), and Smilacina $\left.\left(9 \mu \mathrm{mol} \cdot \mathrm{m}^{-2} \cdot \mathrm{s}^{-1}\right)\right]$, than for Erythronium

Table 3. Separation of means for growth parameters in Geogenanthus undatus C. Koch \& Linden 'Inca' that exhibited an interaction between irradiance level and plant growth regulator (PGR) dosage.

\begin{tabular}{llll}
\hline$P P F$ & PGR (mg/pot) & SDW (g) & LDW (g) \\
\hline $130 \mu \mathrm{mol} \cdot \mathrm{m}^{-2} \cdot \mathrm{s}^{-1}$ & 0.0 & $1.15 \mathrm{a}$ & $4.7 \mathrm{a}^{\mathrm{z}}$ \\
& Ancymidol 0.5 & $0.83 \mathrm{~b}$ & $3.7 \mathrm{~b}$ \\
& Ancymidol 1.0 & $0.71 \mathrm{bc}$ & $3.7 \mathrm{ab}$ \\
& Ancymidol 1.5 & $0.66 \mathrm{bcde}$ & $3.2 \mathrm{bc}$ \\
& Flurprimidol 0.5 & $0.67 \mathrm{bcd}$ & $3.6 \mathrm{~b}$ \\
& Flurprimidol 1.0 & $0.59 \mathrm{cde}$ & $3.2 \mathrm{bc}$ \\
$50 \mu \mathrm{mol} \cdot \mathrm{m}^{-2} \cdot \mathrm{s}^{-1}$ & Flurprimidol 1.5 & $0.62 \mathrm{bcde}$ & $2.9 \mathrm{bc}$ \\
& & & $2.5 \mathrm{c}$ \\
& 0.0 & $0.57 \mathrm{cde}$ & $2.8 \mathrm{bc}$ \\
& Ancymidol 0.5 & $0.56 \mathrm{cde}$ & $2.4 \mathrm{c}$ \\
& Ancymidol 1.0 & $0.46 \mathrm{de}$ & $2.5 \mathrm{c}$ \\
& Ancymidol 1.5 & $0.58 \mathrm{cde}$ & $2.4 \mathrm{c}$ \\
& Flurprimidol 0.5 & $0.49 \mathrm{cde}$ & $2.4 \mathrm{c}$ \\
& Flurprimidol 1.0 & $0.44 \mathrm{e}$ & $2.2 \mathrm{c}$ \\
\hline
\end{tabular}

${ }^{\mathrm{z}}$ Any two means within a column not followed by the same letter are significantly different at $P<0.05$ using a Fisher's LSD mean separation.

$P P F$, photosynthetic photon flux; PGR, plant growth regulator; SDW, stem dry weight; LDW, leaf dry weight.
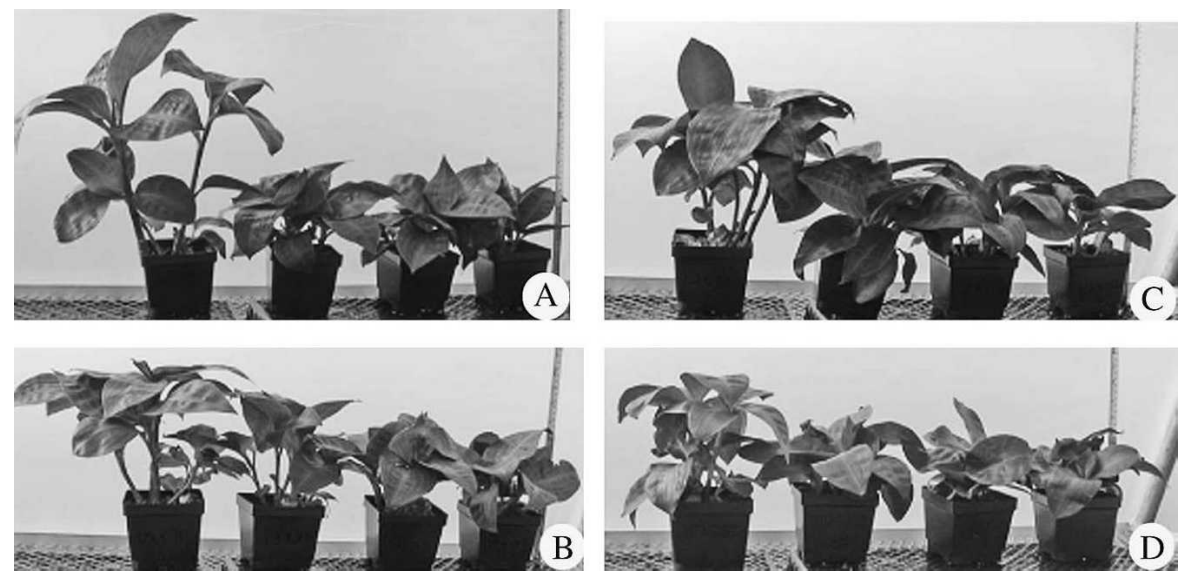

Fig. 1. Growth response of Geogenanthus undatus C. Koch \& Linden 'Inca' to photosynthetic photon flux $(P P F)$ and plant growth regulators after 18 weeks in a simulated postharvest environment. Within panels, right to left: $0.0,0.5,1.0$, and $1.5 \mathrm{mg}$ a.i./pot treatments. (A) High $P P F\left(130 \mu \mathrm{mol} \cdot \mathrm{m}^{-2} \cdot \mathrm{s}^{-1}\right)$, ancymidol. (B) High $P P F$, flurprimidol. (C) Low $P P F\left(50 \mu \mathrm{mol} \cdot \mathrm{m}^{-2} \cdot \mathrm{s}^{-1}\right)$, ancymidol. (D) Low $P P F$, flurprimidol.
(Table 4). Furthermore, there was a difference between the two PGRs; flurprimidoltreated plants were shorter than ancymidoltreated plants. No main or interactive effect involving production $P P F$ was significant with regard to plant height.

The effects of the PGRs are particularly evident upon examination of height increase in simulated interior conditions (i.e., the difference in plant height before and after the postharvest period; Tables 4, 5). The height of untreated plants increased more $(5.9 \mathrm{~cm})$ than that of treated plants, whereas plants treated with flurprimidol had only a very small height increase $(<2.5 \mathrm{~cm})$. Similarly, the growth index increase was lower in PGR-treated plants than in the control plants, and ancymidol-treated plants had a larger increase in growth index than flurprimidol-treated plants. These data indicate that the PGR treatments during late production had extended effects into the postharvest period, and that flurprimidol had a stronger effect during the postproduction phase than ancymidol.

In previous studies, shoot growth also was reduced by PGR applications, after a period in a low- $P P F$ interior environment. Davis (1987) treated three species of foliage plants with paclobutrazol $(25 \mu \mathrm{g} /$ pot a.i.), or $250 \mu \mathrm{g} /$ pot a.i.), and either immediately placed them in a simulated interior environment $\left(P P F, 15 \mu \mathrm{mol} \cdot \mathrm{m}^{-2} \cdot \mathrm{s}^{-1}\right)$ or allowed them to grow for 2 months under optimal greenhouse conditions before being placed in the simulated interior. Paclobutrazoltreated Zebrina (Z. pendula Schnizl.), another member of the Commelinaceae family, experienced almost complete inhibition of growth when immediately placed in an interior environment. However, when greenhouse growth was allowed between PGR treatment and the interior, growth was less than that of control plants in the interior environment. Even though the two concentrations of paclobutrazol were an order of magnitude apart, growth for plants treated with these two concentrations was similar in the interior conditions. In a study using ancymidol drenches, foliage species were grown in a simulated postharvest environment (Blessington and Link, 1980). Height control of treated plants was maintained for Philodendron [P. scandens (Schott) Bunting], Fatshedera [F. lizei (Cochet) Guillaum], and Tradescantia (T. Aluminensis Vell.), a member of the Commelinaceae family.

Shoot and total dry weights were unaffected by production $P P F$ level, PGR type or concentration, or any interactions (Tables 4 and 5). It is interesting that differences were observed between control and treated plants for height and size, but not for total dry weight at the end of the postharvest period. This suggests that the differences in height and size were incited by stem elongation, rather than differences in biomass production. In contrast, at the conclusion of production, high- $P P F$ plants had greater dry weight accumulation, whereas plant height 
Table 4. Growth parameters of Geogenanthus undatus C. Koch \& Linden 'Inca' as affected by plant growth regulator (PGR) type and dosage after an 18-week low photosynthetic photon flux $(P P F)$ postharvest period.

\begin{tabular}{lcccccccc}
\hline PGR (mg/pot a.i.) & $\begin{array}{c}\mathrm{H} \\
(\mathrm{cm})\end{array}$ & $\begin{array}{c}\text { GI } \\
(\mathrm{cm})\end{array}$ & $\begin{array}{c}\text { TDW } \\
(\mathrm{g})\end{array}$ & $\begin{array}{c}\text { RDW } \\
(\mathrm{g})\end{array}$ & $\begin{array}{l}\mathrm{R}: \mathrm{S} \\
\text { CL }\end{array}$ & $\begin{array}{c}\text { H increase } \\
(\mathrm{cm})\end{array}$ & $\begin{array}{c}\text { GI increase } \\
(\mathrm{cm})\end{array}$ \\
\hline Control 0.0 & $22.9 \mathrm{a}^{\mathrm{y}}$ & $30.2 \mathrm{a}$ & $9.4^{\mathrm{z}}$ & $2.96 \mathrm{a}$ & $0.55 \mathrm{a}$ & $5.9 \mathrm{ab}$ & $8.5 \mathrm{a}$ & $5.9 \mathrm{a}$ \\
Ancymidol 0.5 & $17.1 \mathrm{~b}$ & $25.7 \mathrm{~b}$ & 9.7 & $2.97 \mathrm{a}$ & $0.50 \mathrm{ab}$ & $7.2 \mathrm{a}$ & $5.5 \mathrm{~b}$ & $4.4 \mathrm{ab}$ \\
Ancymidol 1.0 & $15.7 \mathrm{bc}$ & $23.7 \mathrm{bc}$ & 8.5 & $2.51 \mathrm{ab}$ & $0.44 \mathrm{abc}$ & $5.4 \mathrm{bc}$ & $4.6 \mathrm{~b}$ & $2.9 \mathrm{bc}$ \\
Ancymidol 1.5 & $14.3 \mathrm{~cd}$ & $23.0 \mathrm{c}$ & 8.4 & $2.47 \mathrm{ab}$ & $0.46 \mathrm{abc}$ & $5.9 \mathrm{ab}$ & $4.2 \mathrm{bc}$ & $2.2 \mathrm{~cd}$ \\
Flurprimidol 0.5 & $12.5 \mathrm{de}$ & $21.4 \mathrm{~cd}$ & 8.3 & $2.35 \mathrm{ab}$ & $0.43 \mathrm{abc}$ & $5.5 \mathrm{bc}$ & $1.6 \mathrm{~d}$ & $0.5 \mathrm{~d}$ \\
Flurprimidol 1.0 & $12.8 \mathrm{e}$ & $20.5 \mathrm{~d}$ & 7.5 & $2.05 \mathrm{~b}$ & $0.40 \mathrm{bc}$ & $5.2 \mathrm{bc}$ & $2.3 \mathrm{~cd}$ & $0.5 \mathrm{~d}$ \\
Flurprimidol 1.5 & $12.2 \mathrm{e}$ & $20.7 \mathrm{~d}$ & 8.9 & $2.18 \mathrm{~b}$ & $0.34 \mathrm{c}$ & $4.2 \mathrm{c}$ & $1.9 \mathrm{~d}$ & $0.9 \mathrm{~d}$
\end{tabular}

${ }^{\mathrm{z}}$ Analysis of variance did not indicate any treatment effects on total dry weight (TDW); therefore, mean separation was not done for this parameter.

${ }^{y}$ Any two values within a column not followed by the same letter are significantly different at $P<0.05$ using pairwise $t$ tests.

The interaction between photosynthetic photon flux and plant growth regulator (PGR) dosage for the growth parameters shown was nonsignificant. Growth index $(\mathrm{GI})$ and height $(\mathrm{H})$ increase refer to the increase in the postharvest environment.

a.i., active ingredient; RDW, root dry weight; R:S, root-to-shoot ratio; SL, senesced leaves.

Table 5. Analysis of variance of main effects and contrast statements for the effects of the photosynthetic photon flux $(P P F)$ and plant growth regulator (PGR) on morphological response in Geogenanthus undatus $\mathrm{C}$. Koch \& Linden 'Inca' after 8 weeks in a low $P P F$ postharvest environment.

\begin{tabular}{|c|c|c|c|c|c|c|c|c|c|}
\hline \multirow[b]{2}{*}{ Effect $^{2}$} & \multicolumn{9}{|c|}{ Growth parameters } \\
\hline & $\mathrm{H}$ & GI & SDW & TDW & RDW & $\mathrm{R}: \mathrm{S}$ & SL & $\mathrm{H}$ increase & GI increase \\
\hline$\overline{P P F}$ & NS & NS & NS & NS & NS & 0.04 & NS & NS & NS \\
\hline PGR treatments & $<0.0001$ & $<0.0001$ & NS & NS & 0.04 & 0.05 & 0.009 & $<0.0001$ & $<0.0001$ \\
\hline$P P F \times \mathrm{PGR}$ treatments & NS & NS & NS & NS & NS & NS & NS & NS & NS \\
\hline All PGRs vs. control & $<0.0001$ & $<0.0001$ & - & - & 0.03 & 0.01 & NS & $<0.0001$ & $<0.0001$ \\
\hline PGR A vs. control & $<0.0001$ & $<0.0001$ & - & - & NS & NS & NS & $<0.0001$ & 0.002 \\
\hline PGR F vs. control & $<0.0001$ & $<0.0001$ & - & - & 0.005 & 0.003 & NS & $<0.0001$ & $<0.0001$ \\
\hline PGR A vs. PGR F & $<0.0001$ & $<0.0001$ & - & - & 0.02 & 0.05 & 0.007 & $<0.0001$ & $<0.0001$ \\
\hline Concentration effect & NS & 0.04 & — & - & NS & NS & 0.03 & NS & NS \\
\hline $\begin{array}{l}\text { Concentration effect, } \\
\text { linear }\end{array}$ & NS & 0.02 & - & - & NS & NS & 0.01 & NS & NS \\
\hline
\end{tabular}

${ }^{\mathrm{z}}$ Use of contrast statement analysis was based on significance of corresponding main effect at a level of $P<0.05$.

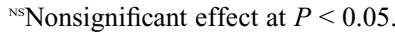

Growth index (GI) and height $(\mathrm{H})$ increase refer to the increase in the postharvest environment.

SDW, shoot dry weight; TDW, total dry weight; RDW, root dry weight; R:S, root-to-shoot ratio; SL, senesced leaves; PGR A, ancymidol; PGR F, flurprimidol.

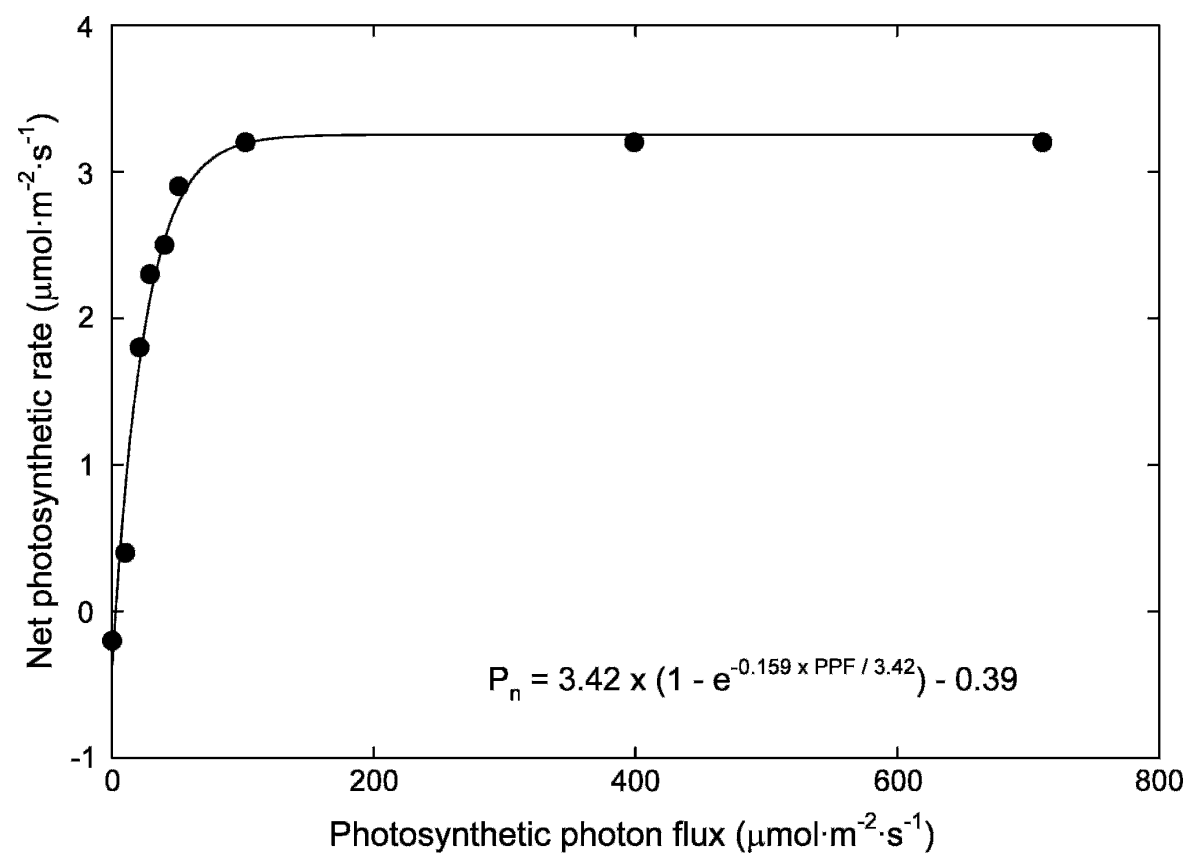

Fig. 2. Typical photosynthetic response to increasing photosynthetic photon flux $(P P F)$ levels for Geogenanthus undatus C. Koch \& Linden 'Inca'. The regression curve shown is the average of 12 representative curves. $\mathrm{P}_{\mathrm{n}}$, net photosynthetic concentration. did not differ between the $P P F$ treatments compared with low- $P P F$ plants.

Root dry weight was reduced by flurprimidol but not by ancymidol (Tables 4 and 5). However, production $P P F$, or the interaction of production $P P F$ with PGRs, did not affect root dry weight. Root dry weight has been shown to increase in rice (Oryza sativa L.) roots (Yim et al., 1997), but decrease in citrus seedlings (Mehouachi et al., 1996) in response to PGRs.

There was no interaction between production $P P F$ and PGR treatment for root-toshoot ratio, but their main effects were significant (Tables 4 and 5). Low-PPF plants had consistently greater root-to-shoot ratios (average, 0.51) than high- $P P F$ plants (average, 0.38 ). This is in contrast to what would be expected, because low-light plants often invest a larger fraction of their carbon resources in the shoot (Taiz and Zeiger, 2002). Plant growth regulator effects on root-to-shoot ratios were related to effects on root dry weight; flurprimidol applications reduced both root dry weight and the root-to-shoot ratio, whereas ancymidol applications did not.

Leaf senescence was unaffected by $P P F$. The number of dropped leaves also was unaffected by production $P P F$ for two species of Schefflera (S. arboricola Hayata ex. Kanehira and Brassaia actinophylla Endl) after 3 months in a simulated interior environment (Braswell et al., 1982). However, PGRs have been shown to affect the number of senesced leaves in members of the Commelinaceae family. After application of paclobutrazol, $Z$. pendula plants had fewer senesced leaves (Davis, 1987). In the current study, flurprimidol-treated plants had fewer senesced leaves than ancymidol-treated plants (Tables 4 and 5). Although statistical significance was not found between PGR-treated plants and controls, in general the treated plants appeared to have fewer senesced leaves.

In conclusion, applications of ancymidol or flurprimidol administered to $G$. undatus C. Koch \& Linden 'Inca' late during the production cycle resulted in significant growth control and, therefore, superior plant performance throughout the postharvest period. Production $P P F$ did not play a major role in the overall response of the plants to the interior environment. Therefore, growers may use the high-production PPF $\left(130 \mu \mathrm{mol} \cdot \mathrm{m}^{-2} \cdot \mathrm{s}^{-1}\right)$, which results in a greater accumulation of dry weight than the low PPF $\left(50 \mu \mathrm{mol} \cdot \mathrm{m}^{-2} \cdot \mathrm{s}^{-1}\right)$. Furthermore, although PGRs effectively controlled height and growth index, the PGR concentration did not exert great influence over these parameters. Thus, the lower, more economical concentration can be used successfully. In general, flurprimidol exerted greater control over plant growth than ancymidol, and thus shows promise for use as a growth regulator in the foliage industry.

\section{Literature Cited}

Blessington, T.M. and C.B. Link. 1980. Influence of ancymidol on four species of tropical foliage plants under different artificial light intensities. J. Amer. Soc. Hort. Sci. 105:502-504. 
Braswell, J.H., T.M. Blessington, and J.A. Price. 1982. Influence of cultural practices on postharvest interior performance of two species of Schefflera. HortScience 17:345347.

Conover, C.A. and R.T. Poole. 1981. Environmental factors, p. 269-283. In: J. Joiner (ed.). Foliage plant production. Prentice-Hall, Englewood Cliffs, N.J.

Cox, D.A. and F.F. Whittington. 1988. Effects of paclobutrazol on height and performance of aluminum plant in a simulated interior environment. HortScience 23:222.

Davis, T.D. 1987. Interior performance of three foliage plant species treated with paclobutrazol. Appl. Agr. Res. 2:120-123.

Davis, T.D., G.L. Steffens, and N. Sankhla. 1988. Triazole plant growth regulators, p. 63-105. In: J. Janick (ed.). Horticultural reviews. Vol. 10. Timber Press, Portland, Ore.

Graf, A.B. 1963. Exotica. Pictorial cyclopedia of exotic plants. Roehrs Co., Rutherford, N.J.

Hull, J.C. 2002. Photosynthetic induction dynamics to sunflecks of four deciduous understory herbs with different phonologies. Int. J. Plant Sci. 163:913-924. lo Bianco, R. and M. Rieger. 2002. Roles of sorbitol and sucrose in growth and respiration of 'Encore' peaches at three developmental stages. J. Amer. Soc. Hort. Sci. 127:297-302.

Makino, A., T. Sato, H. Nakano, and T. Mae. 1997. Leaf photosynthesis, plant growth and nitrogen allocation in rice under different irradiances. Planta 203:390-398.

Mehouachi, J., F.R. Tadeo, S. Zaragoza, E. PrimoMillo, and M. Talon. 1996. Effects of gibberellic acid and paclobutrazol on growth and carbohydrate accumulation in shoots and roots of citrus rootstock seedlings. J. Hort. Sci. 71:747-754.

Pennisi, S.V., J. Chen, and D.B. McConnell. 2003. Plant growth regulator application improves the interior performance of three Dieffenbachia cultivars. HortScience 38:714.

Reed, D.W. 1996. A grower's guide to water, media, and nutrition for greenhouse crops. Ball, Batavia, Ill.

Starman, T.W., J.W. Kelly, and H.B. Pemberton. 1989. Characterization of ancymidol effects on growth and pigments of Helianthus annuus cultivars. J. Amer. Soc. Hort. Sci. 114:427-430.

Taiz, L. and E. Zeiger. 2002. Plant physiology. 3rd ed. Sinauer Associates, Inc., Sunderland, Mass.
Thetford, M., S.L. Warren, and F.A. Blazich. 1995 Response of Forsythia $x$ intermedia 'Spectabilis' to uniconazole I. growth, dry-matter distribution, mineral nutrient content, concentration, and partitioning. J. Amer. Soc. Hort. Sci. 120:977-982.

Vladimirova, S.V., D.B. McConnell, M.E. Kane, and R.W. Henley. 1997. Morphological plasticity of Dracaena sanderiana 'Ribbon' in response to four light intensities. HortScience 32:1049-1052.

Whipker, B.E., I. McCall, J.L. Gibson, and T.J. Cavins. 2004. Flurprimidol foliar sprays and substrate drenches control growth of 'Pacino' pot sunflowers. HortTechnology 14:411-414.

Yeager, T., C. Gilliam, T. Bilderback, D. Fare, A. Niemiera, and K. Tilt. 1997. Best management practices: Guide for producing containergrown plants. Southern Nurserymen's Association, Marietta, Ga.

Yim, K.-O., Y.W. Kwon, and D.E. Bayer. 1997. Growth responses and allocation of assimilates of rice seedlings by paclobutrazol and gibberellin treatment. J. Plant Growth Regul. 16: 35-41. 